\title{
Major Causes of Saudi Learners' Speaking Anxiety in EFL Classrooms
}

\author{
Suzan Hammad Rafada \\ English Language Institute, King Abdulaziz University, Jeddah, Saudi Arabia \\ E-mail: srafada@kau.edu.sa
}

Abeer Ahmed Madini (Corresponding author)

English Language Institute, King Abdulaziz University, Jeddah, Saudi Arabia

E-mail: Amadini@kau.edu.sa

Received: January 3, 2017 Accepted: January 19, 2017 Published: January 24, 2017

doi:10.5296/ijele.v5i1.10645 URL: http://dx.doi.org/10.5296/ijele.v5i1.10645

\begin{abstract}
Since oral participation is one of the most observable phenomena in language classes, it has been noticed that students often suffer from a considerable level of anxiety in EFL classrooms. Although numerous studies have tackled this issue, particular attention to Saudi learners' perspectives of the main causes of speaking anxiety is needed. Therefore, this research aims to explore the main causes of speaking anxiety that Saudi EFL learners encounter in their language classrooms. The sample of this study involved 126 ELI Saudi female students studying their foundation year at King Abdulaziza University and whose ages range between 18 to 20 years old. To reach a better and clear understanding of the research phenomenon, a mixed- method approach was used. For gathering data, two instruments were utilized; a semi-structured interview with ten students from level 102, 103, and 104 and an online based questionnaire with 116 students from level 102 and 103. The quantitative data were analyzed through descriptive statistics, and the qualitative data were thematically analyzed. The qualitative data found that the main causes of speaking anxiety were: Teachers' role in raising or reducing anxiety, lack of vocabulary, the weak educational system at schools, test anxiety, and peer anxiety. On the other hand, the quantitative data categorized speaking anxiety into three main domains: causes related to the classroom atmosphere, causes related to the EFL teachers, and others related to the test.
\end{abstract}

Keywords: Foreign language anxiety, Speaking anxiety, Saudi EFL learners 


\section{Introduction}

In the past research, the focus in the area of second language acquisition (SLA) has been mainly on language pedagogy, such as teaching methods and approaches. That is to say; research has paid much attention to teaching and learning itself and the cognitive domain of the learner rather than pinpointing the affective variables that learners bring with them into class (Tseng, 2012). In the early 1970s, researchers started to investigate some of the affective variables that may hinder the whole learning process, such as learning styles, motivation, individual differences and anxiety (Shams, 2006). These variables, in fact, appeared to be relevant even in today's classroom. Therefore, teachers, as well as educators, should put these affective variables into consideration to have a better understanding of their students' needs and interests. The current paper highlights one of these instrumental variables, which is students' anxiety in EFL classrooms, with particular reference to speaking, among Saudi EFL learners.

\section{Literature Review}

\subsection{What is Language Anxiety?}

Language anxiety had been established as a discrete topic and an issue peculiar to foreign language learning (Alsaraj, 2014). The concept of language anxiety had been defined in numerous studies in the field of foreign language education since the early 1970s (Gardner \& MacIntyre, 1993; Horwitz, Horwitz, \& Cope, 1986; Young, 1992; Alsaraj, 2014; Alrabai, 2015). Young (1992), for instance, described language learning contexts as the provoking factor for language anxiety and defined language anxiety as a construct peculiar to language learning situations. Also, Gardner and MacIntyre (1993) provided a more precise definition for language anxiety when they described it as " the apprehension experienced when a situation requires the use of a second language with which the individual is not fully proficient." (p. 5)

The concept foreign language anxiety (FLA) was conceived as a complex and multidimensional phenomenon (Young, 1990). As an illustration, Horwitz, Horwitz, \& Cope (1986) defined (FLA) as "a distinct complex of self-perceptions, feelings, and behaviors related to classroom language learning arising from the uniqueness of the language learning process " (p. 128). The current research was based on Horwitz et al.'s notion of anxiety, as learning a foreign language could be perceived a stressful experience that involved complicated feelings of apprehension and discomfort which could hinder the students' whole learning process.

\subsection{The Causes of Speaking Anxiety}

After the admission of language anxiety as a separate construct (Horwitz, Horwitz, \& Cope, 1986). Researchers began to investigate the causes and effects of speaking anxiety on EFL learners (e.g., MacIntyre \& Gardner, 1991; Yahya, 2013; Öztürk \& Gürbüz, 2014; Mukminin et al., 2015). The following section provides a literature review of the different causes of speaking anxiety in the language classroom. 


\subsubsection{Competitiveness and Classroom Atmosphere}

A considerable number of investigators identified competitiveness as essential in determining students' speaking anxiety. As an illustration, Curtrone (2009) explored that inter-learner competition is one of the main causes of Japanese EFL learners' language anxiety. Moreover, Kayaoglu \& Saglamel (2013) related students' speaking anxiety in Bond University, English Language Institute, Australia, to the fear of failure in front of others, competitiveness and fear of making mistakes. Besides, Öztürk \& Gürbüz (2014) discussed some situations in which Turkish EFL students felt stressed while speaking inside the classroom, such as forgetting appropriate words, not being prepared to talk as they are sometimes embarrassed to speak in front of the class or exposed to the questions immediately. In a similar way, Young's (2004) qualitative study found that the main causes of Korean EFL University students foreign language anxiety was the students' low self-esteem, competitiveness among their peers, situation-specific anxiety, and lack of group membership. He also added, overt explicit error correction, speaking English in front of the class, limited knowledge, lack of class preparation, and uneven allowance of turns as other causes of FLA. In India, Ansari (2015) also conducted a case study on students' perception, performance, and main causes of speaking anxiety. He found that fear of peers negative evaluation was one of the major causes of speaking anxiety that the participants may encounter.

\subsubsection{Unsupportive Teachers}

A number of studies in the field of foreign language speaking anxiety proved that teachers constitute as an essential cause in students' low ability in language learning. In the literature, preparing the students mainly for the exam, using traditional methods of teaching without considering the students' needs, and teachers' negative evaluation were among the main causes of speaking anxiety caused by the teacher. In China, Shuying (1999), for instance, pointed out that preparing for national tests still the main concern for most Chinese teachers while they ignored the communicative skills where learners require real situations to practice the language. Yahya (2013) further claimed that college students lacked competency in speaking, and most have difficulties with pronunciation due to teachers' use of traditional methods of teaching, which made them unwilling to communicate in the target language. Mukminin et al. (2015) added another view concerning the role of the teacher in causing language learning anxiety. The researchers mentioned that the fear of being evaluated by teachers was considered one of the causes shared by students. One of their participants stated: "My English teacher is more knowledgeable, so I am anxious to speak English with him". This statement indicates that students had a fear of making mistakes in front of their teachers as they conceived them as more competent in English.

\subsubsection{Test Anxiety}

Previous research identified that test anxiety was one of the significant factors that affected EFL learners in the learning process. According to Horwitz, Horwitz, \& Cope (1986), the third component of language anxiety was test-anxiety, besides communication apprehension and the students' fear of negative evaluation either from teachers or peers. Traditionally, test-anxiety was defined as "a type of performance anxiety stemming from a fear of failure " 
(Gordon \& Sarason (1955), as cited in Horwitz, Horwitz \& Cope, 1986; p. 127). Hamouda (2013) found out in his study that $67.92 \%$ of Saudi students feel more anxious during oral tests. He claimed that it is essential to "note that oral testing has the potential to provoke both test and oral communication anxiety simultaneously " (p. 27). Furthermore, Kayaoğlu \& Sağlamel (2013) asserted that the fear of exams fostered an "intimidating atmosphere for students" (p. 151). Since the past research explored the negative impact of test anxiety on EFL learners' oral performance, it was essential for this study to tackle this cause of anxiety.

\subsection{Speaking Anxiety in the Saudi context}

Few studies had explored the negative effects of foreign language anxiety (FLA) among Saudi students. To examine the causes behind Saudi students' low speaking proficiency, Alhamadi (2014) conducted a qualitative study by observing 10 English speaking classes for the foundation year students at Tibah University. She stated that anxiety was a prominent factor that had a negative impact on language learning. She recommended at the end of her research that the educational system in Saudi Arabia for teaching second languages should be reformed.

A quantitative study by Alrabai (2015), investigated the level and sources of the anxiety of Saudi EFL university students by using the Foreign Language Classroom Anxiety Scale (FLCAS) through a period of three years. The number of participants of his study was 1,389 Saudi students. The research findings showed that the main cause of anxiety among participants was their communication apprehension due to lack of preparation before the English class.

In addition, students' limited participation in EFL classrooms was considered to be another cause for students' speaking low proficiency which then led to their anxiety. As an illustration, in her study, Alharbi (2015) asserted that "students are listeners and receivers of knowledge" (p. 107). They did not have a chance to speak a sufficient time in class that allowed them to improve their language. Furthermore, Jamjoom (2009) claimed that "students' participation in classroom is limited to one or two sentence responses to questions " (as cited in Alharbi, 2015, p. 107). Students' participation is essential as they need to practice the language and use it daily to improve their language proficiency.

\subsection{Gap in the Literature}

From the above studies, we can conclude that few Saudi researchers have investigated the causes of foreign language anxiety (FLA) and its effect on the learning process. In fact, no study in the Saudi EFL context has tackled the causes of anxiety among female participants studying in the English Language Institute (ELI), the context of this research. In addition, most of the Saudi studies investigated the causes of speaking anxiety either quantitatively or qualitatively. Therefore, the present study aimed to utilize both quantitative and qualitative methods to shed light on the main causes of FLA among Saudi learners from their perspective.

This study aimed to answer the following research question: 
1) What are the main causes of Saudi students' speaking anxiety in EFL classrooms?

\section{Methodology}

\subsection{Theoretical Framework}

Traditionally, there were three components of foreign language anxiety identified by (Horwitz, Horwitz, \& Cope, 1986). Horwitz et al. argued that there were three related performance anxieties: the first one was called communication apprehension; the second was students' fear of negative evaluation; while the third was test-anxiety. These three authors defined communication apprehension as "a type of shyness characterized by fear of or anxiety about communicating with people" (p.127). As a matter of fact, communication apprehension played a major role in foreign language anxiety. Individuals who have this feeling of communication apprehension usually do not communicate freely in the target language especially in front of their peers due to their limited knowledge (Al Ansari, 2015).

The second component of FLA, according to Horwitz et al. (1986), was the students' fear of negative evaluation. Those students always have a fear of losing face in front of their teacher or their peers. For this reason, they do not usually participate in class discussions as they "do not consider language errors as a natural part of the learning process, but as a threat to their image " (Al Ansari, 2015, p. 39).

The third component of language anxiety was Test-anxiety. It is defined as "a type of performance anxiety stemming from a fear of failure " (Gordon \& Sarason (1955), as cited in Horwitz, Horwitz \& Cope, 1986 p. 127). Test-anxious students do not usually deal with tests as a way of improving their language abilities but rather as a test situation where their anxiety level increases.

Since the present study aimed to investigate the main causes that raise anxiety during the language learning process, the researchers found Horwitz' theory of the three components of foreign language anxiety closely related to their research. In other words, Horwitz's theory had been mentioned in a considerable number of studies due to its importance. Many studies conducted afterward adopted their theoretical model. In addition, the researchers had been guided with the help of Horwitz's theory in writing both the interview questions and the questionnaire items.

\subsection{Research Design}

In this research, the mixed-method design was applied to provide multiple perspectives and a better understanding of the research question under investigation. Using a mixed method research allowed researchers to "provide a better understanding of the research problem and question than either method by itself" (Creswell, 2012; p. 535). In contrast to the previous Saudi-based research on speaking anxiety, researchers used only one method (Alhamadi, 2014; and Alrabai, 2015), the current research aimed at applying a mix-method design as multiple insights to the research question permitted a better conception. Conducting the mixed-method research design also ensured no gaps to the data collected, which consequently led to greater validity. 


\subsection{Data Collection Procedure}

The researchers started with collecting qualitative data and then gathered quantitative data. This process is called "The exploratory sequential design". According to Creswell (2012), "The purpose of an exploratory sequential mixed methods design involves the procedure of first gathering qualitative data to explore a phenomenon and then collecting quantitative data to explain relationships found in the qualitative data " (p. 543). Therefore, the first method used was semi-structured interviews with ten students studying their foundation year at the English Language Institute (ELI). Based on the themes of the interview and the literature review, then the second method was used that is an online based Likert-scale questionnaire to identify the main causes of the Saudi female learners' speaking anxiety inside the EFL classroom.

\subsubsection{Semi-structured Interviews}

To gain an in-depth understanding of students' perceptions on causes of speaking anxiety in EFL classes, semi-structured interviews were conducted. In this study, ten Saudi female students from the elementary, pre-intermediate and intermediate levels (levels 102,103, and 104) were interviewed. The interviews were conducted in Arabic and then translated into English to overcome the language barrier which could negatively affect the validity and reliability of the data. The semi-structured interview format was selected due to its flexibility. The interviewees were allowed to speak broadly on the phenomenon and to develop ideas on the issues raised by the researcher during the interview (Denscombe, 2014). Therefore, utilizing semi-structured interviews enhanced the researchers' knowledge of the research problem and overcame their biases.

\subsubsection{Questionnaire}

In this article, a foreign language speaking anxiety questionnaire was designed by selecting nine questionnaire items from the 33 items of FLCAS developed by Horwitz, Horwitz, \& Cope (1986). Then combined with nine more items from Alsaraj (2014)'s questionnaire to end up with a more comprehensible questionnaire that better suits the participants of this study. Alsaraj had modified the Foreign Language Classroom Anxiety Scale previously designed by Horwitz, Horwitz, \& Cope (1986) to assess Saudi female students' anxiety studying in Saudi Arabia, and named it the Arabic foreign language classroom anxiety scale (AFLCAS). The researchers found it suitable for their research as it matched the common problems appeared in the interviews in this study .

A Google form service was used to construct the questionnaire. It consisted of 18 question items and divided into four parts. The first part elicited the demographic information about the participants' age and academic level. The second part consisted of items which dealt with causes of speaking anxiety related to the classroom atmosphere. The third part of the questionnaire highlighted causes of speaking anxiety related to the EFL teacher, while the final part dealt with the causes of speaking anxiety associated with the exam and students' grades. The questionnaire was distributed through a snowballing technique, translated into Arabic, and measured by a five-point, Likert-scale (ranging from strongly agree on $=5$, to 
strongly disagree $=1$ ).

\subsubsection{Piloting the Questionnaire}

To measure the survey reliability, it was checked by some qualified faculty members in the ELI's Women's Campus and then pilot tested by administering it to 5 students in the English language institute. Cronbach Alpha was used to compute the reliability of the students' questionnaire. Its reliability was 0.779 . The reliability coefficient indicated that the data collected were highly reliable.

\subsection{Participants and Sampling}

A total of $(\mathrm{N}=126)$ participants were sampled from different ELI's foundation year students at King Abdul Aziz University Women's Main Campus and the Women's colleges. The ELI follows an integrated skills program of four modules, two in each academic semester. The program consists of four levels correlated to the Common European Framework References for Languages (CEFR). It is an international standard that describes language ability. All contributors in the study were Saudi female students who were native speakers of Arabic, aged from 18 up to 20 years old. They all placed at different proficiency levels at the ELI and were informed about the research topic and its aims before accepting to join the study.

\section{Results}

\subsection{What Are the Main Causes of Saudi Students' Speaking Anxiety in EFL Classrooms?}

\subsubsection{Qualitative Results}

The qualitative data was thematically analyzed using Nvivo10. During the interviews, the researchers found out key themes concerning the causes of students' speaking anxiety. These themes were:

\subsubsection{Teachers' Role in Raising or Reducing Anxiety}

The findings indicated that the teacher played a vital role in raising or reducing speaking anxiety among learners. Six participants out of ten described their teachers as unsupportive and sometimes humiliating. For example, student A (level 102) claimed: "The teachers did not encourage us to be confident". Student B (level 102) indicated: "The teachers do not teach us how to speak and they do not create new activities that allow us to speak and practice the language". The difficulty to understand the teacher's language was considered another cause that aroused the participants' anxiety. Five participants suffered from the difficulty to understand their teachers, especially the native teachers. As an illustration, student I (level 104) added: "I don't understand the teacher because she is talking in English all the time. I feel that I am wasting my time attending English classes without understanding". Some participants expressed their fear of making mistakes in front of the teacher for example, student A (level 102) said: "I get nervous because I do not want to make any mistakes in front of the teacher". In addition, participants revealed that during English classes, teachers often talk more than their students. They demanded to have more time for participating and practicing English during class. As an illustration, student G (level 103) said: 


\section{Macrothink}

"We are using the books most of the time. The teacher is talking most of the time and we need to speak English as well in order to practice the language". Student B (level 102) reported: "From level one, the teachers do not teach us how to speak, they only focus on grammar and they do not make a class discussion in order to give us a chance to speak". To conclude, the most common themes found concerning the relationship between the teacher and students are the lack of support, lack of understanding due to language barrier, the fear of the teacher's negative feedback and time limitation for practicing the target language inside the classroom.

\subsubsection{Lack of Vocabulary}

The second theme that emerged from the interviews was the students' lack of vocabulary. This problem, as some of the participants revealed, may affect their performance and raise their speaking anxiety. For instance, student A (level 102) said: "I do not have enough words that help me express myself". Student J also reported: "I am not confident and I do not have enough words to express myself in speaking".

\subsubsection{Weak Education at Schools}

Seven out of ten respondents revealed that the main reason for their foreign language speaking anxiety is linked to the weak Saudi educational system that they experienced at schools. Student A, D, E, G, H, I, J asserted that they are not used to speak in the target language. For example, student J (level 104) said: "I do not have a good background in English as our education at schools was weak". While student E (level 102) added: "Our proficiency level is low due to our weak education at schools". Another participant stated: "At schools we have only one hour to learn English which is not enough to master the language".

\subsubsection{Test Anxiety}

Four participants referred their speaking anxiety to the fear of failure. In fact, students were afraid to fail in the English speaking tests; therefore they got anxious especially during their speaking assessments. Student E (level 102) said: "If I fail in the test I will feel depressed". Student G (level 103) added: "I am having level 2 for the second time now and I feel scared if I fail for the third time".

\subsubsection{Peer Anxiety}

Half of the interviewees showed their fear of negative evaluation from their classmates. For example, student B (level 102) said: "I am afraid if I make a mistake or mispronounce the words because my classmates may laugh at me". Moreover, student H (level 104) asserted: "I feel nervous if I speak in front of my classmates because if I say a wrong answer they may laugh". Then she added "I feel anxious when my classmates laugh at my pronunciation".

\subsubsection{Quantitative Results}

In this study, 116 female students were selected to answer the online questionnaire. In order to analyze the quantitative data, SPSS 20 was utilized for descriptive statistical analysis of frequencies and percentages. 


\section{Al Macrothink}

\subsubsection{Demographic Information}

The first part of the questionnaire was related to demographical data about the participants, which comprised of students' age and academic level. The total number of participants who participated in the quantitative data $(\mathrm{N}=116) .54(46.6 \%)$ students were enrolled in level 102, whereas $62(53.4 \%)$ students were registered in level 103. Both groups were from elementary to pre- intermediate levels. The participants' age ranged between 18-20 years old.

\subsubsection{The Questionnaire Analysis}

The questionnaire consisted of 18 items with three main sections: First, the causes of speaking anxiety related to the classroom, second, the causes of speaking anxiety associated with the teacher, and third, the causes of speaking anxiety related to the test.

\subsection{Causes Related to Classroom Atmosphere}

Table 1 below illustrates the main causes of the Saudi female learners' speaking anxiety in relation to their classroom atmosphere; this section covers 11 questionnaire items.

Table 1. Causes related to classroom atmosphere

\begin{tabular}{|c|c|c|c|c|c|c|c|c|c|c|c|c|}
\hline & SD & & D & & $\mathbf{N}$ & & $\mathbf{A}$ & & SA & & $(-)$ & $(+)$ \\
\hline Items & $\mathrm{N}$ & $\%$ & $\mathrm{~N}$ & $\%$ & $\mathrm{~N}$ & $\%$ & $\mathrm{~N}$ & $\%$ & $\mathrm{~N}$ & $\%$ & $\%$ & $\%$ \\
\hline $\begin{array}{l}\text { 1. In a language class, I can } \\
\text { get so nervous I forget } \\
\text { things I know. }\end{array}$ & 12 & 10.3 & 25 & 21.6 & 28 & 24.1 & 24 & 20.7 & 27 & 23.3 & 31.9 & 44 \\
\hline $\begin{array}{l}\text { 2. I keep thinking that the } \\
\text { other students are better at } \\
\text { languages than I am. }\end{array}$ & 27 & 23.3 & 23 & 19.8 & 19 & 16.4 & 23 & 19.8 & 24 & 20.7 & 43.1 & 40.5 \\
\hline $\begin{array}{l}\text { 3. I often prefer not going } \\
\text { to my language class. }\end{array}$ & 27 & 23.3 & 17 & 14.7 & 19 & 16.4 & 18 & 15.5 & 35 & 30.2 & 38 & 45.7 \\
\hline $\begin{array}{l}\text { 4. I feel confident when I } \\
\text { speak in a foreign language } \\
\text { class. }\end{array}$ & 21 & 18.1 & 16 & 13.8 & 28 & 24.1 & 18 & 15.5 & 33 & 28.4 & 31.9 & 43.9 \\
\hline $\begin{array}{l}\text { 5. I feel more tense and } \\
\text { nervous in my language } \\
\text { class than in my other } \\
\text { classes. }\end{array}$ & 32 & 27.6 & 14 & 12.1 & 24 & 20.7 & 18 & 15.5 & 28 & 24.1 & 39.7 & 39.6 \\
\hline $\begin{array}{l}\text { 6. I am nervous and } \\
\text { confused when I am } \\
\text { speaking in my language } \\
\text { class in front of other } \\
\text { students. }\end{array}$ & 21 & 18.1 & 24 & 20.7 & 17 & 14.7 & 30 & 25.9 & 24 & 20.7 & 38.8 & 46.6 \\
\hline
\end{tabular}


7. I am afraid that other 44

37.92

18.119

16.410

8.6

$\begin{array}{lll}22 & 19.0 & 56\end{array}$

27.6 students will laugh at me when I speak the foreign language.

\begin{tabular}{|c|c|c|c|c|c|c|c|c|c|c|c|c|}
\hline $\begin{array}{l}\text { 8. I feel nervous when I } \\
\text { can't write or express } \\
\text { myself in the foreign } \\
\text { language. }\end{array}$ & 16 & 13.8 & 18 & 15.5 & 22 & 19.0 & 19 & 16.4 & 41 & 35.3 & 29.3 & 51.7 \\
\hline $\begin{array}{l}\text { 9. I fear pronouncing words } \\
\text { incorrectly in my foreign } \\
\text { language class. }\end{array}$ & 24 & 20.7 & 20 & 17.2 & 19 & 16.4 & 21 & 18.1 & 32 & 27.6 & 37.9 & 45.7 \\
\hline $\begin{array}{l}\text { 10.I feel anxious when I } \\
\text { want to volunteer to say } \\
\text { something but can't find the } \\
\text { proper words to say it in } \\
\text { my foreign language class }\end{array}$ & 12 & 10.3 & 24 & 20.7 & 16 & 13.8 & 17 & 14.7 & 47 & 40.5 & 31 & 55.2 \\
\hline $\begin{array}{l}\text { 11. I feel nervous when } \\
\text { standing to give a } \\
\text { presentation in front of the } \\
\text { class. }\end{array}$ & 19 & 16.4 & 13 & 11.2 & 19 & 16.4 & 21 & 18.1 & 44 & 37.9 & 27.6 & 56 \\
\hline
\end{tabular}

Note: $S A=$ strongly agree, $A=$ Agree, $N=$ neutral, $\mathrm{D}=$ disagree, $S D=$ Strongly disagree, $(-)=$ Disagree + strongly disagree, $(+)=$ agree + strongly agree

The above table indicates the causes of speaking anxiety that the Saudi EFL learners may encounter in their English language classroom. It shows that (43.1\%) of them are not having a fear of competitiveness while $(40.5 \%)$ have this kind of anxiety. Concerning students' communication apprehension, nearly half of the participants (46.6\%) feel anxious and confused when they speak English in front of other students in comparison to (38.8\%) who do not. However, the data shows that $(56 \%)$ of the participants do not have peers' anxiety, while only $(27.6 \%)$ of the participants do. This finding indicates that more than half of the participants did not experience the fear of negative evaluation from their classmates. The students' lack of vocabulary was considered to be the most anxiety-provoking item in the speaking class, $(55.2 \%)$ agreed that they feel anxious when they want to volunteer in class discussions because they don't have enough words in the target language, in comparison to (31\%) who disagreed. A similar result also appeared for the last questionnaire item which was, discussing the students' fear of giving a presentation in front of the whole class. In fact, Table 1 reveals that $(56 \%)$ of the students indicate that they feel anxious when they present any topic in the target language in front of the class, in comparison to the minor (27.6\%) who claims that they do not. 


\subsection{Causes Related to the EFL Teacher}

Table 2 below displays the causes of speaking anxiety about the EFL teacher. This section covers five questionnaire items.

Table 2. Causes related to the EFL teacher

\begin{tabular}{|c|c|c|c|c|c|c|c|c|c|c|c|c|}
\hline & SD & & D & & $\mathbf{N}$ & & $\mathbf{A}$ & & $\mathbf{S A}$ & & $(-)$ & $(+)$ \\
\hline Items & $\mathrm{N}$ & $\%$ & $\mathrm{~N}$ & $\%$ & & $\%$ & $\mathrm{~N}$ & $\%$ & $\mathrm{~N}$ & $\%$ & $\%$ & $\%$ \\
\hline $\begin{array}{l}\text { 12. I feel anxious when } \\
\text { the teacher asks me a } \\
\text { question that I have not } \\
\text { prepared for. }\end{array}$ & 13 & 11.2 & 16 & 13.8 & 21 & 18.1 & 25 & 21.6 & 41 & 35.3 & 25 & 56.9 \\
\hline $\begin{array}{l}\text { 13. I am afraid that my } \\
\text { language teacher is } \\
\text { ready to correct every } \\
\text { mistake I make. }\end{array}$ & 37 & 31.9 & 26 & 22.4 & 25 & 21.6 & 13 & 11.2 & 15 & 12.9 & 54.3 & 24.1 \\
\hline $\begin{array}{l}\text { 14. I feel nervous and } \\
\text { confused when the } \\
\text { language teacher is } \\
\text { unsuccessful in } \\
\text { explaining the lesson. }\end{array}$ & 23 & 19.8 & 14 & 12.1 & 26 & 22.4 & 19 & 16.4 & 34 & 29.3 & 31.9 & 45.7 \\
\hline $\begin{array}{l}\text { 15. I feel comfortable in } \\
\text { speaking with my } \\
\text { foreign language } \\
\text { teacher. }\end{array}$ & 20 & 17.2 & 21 & 18.1 & 31 & 26.7 & 18 & 15.5 & 26 & 22.4 & 35.3 & 37.9 \\
\hline $\begin{array}{l}\text { 16. I feel anxious when } \\
\text { I don't understand } \\
\text { what the teacher is } \\
\text { saying in the foreign } \\
\text { language. }\end{array}$ & 17 & 14.7 & 17 & 14.7 & 18 & 15.5 & 25 & 21.6 & 39 & 33.6 & 29.4 & 55.2 \\
\hline
\end{tabular}

Note: $S A=$ strongly agree, $A=$ Agree, $N=$ neutral, $\mathrm{D}=$ disagree, $S D=$

Strongly disagree,$(-)=$ Disagree + strongly disagree,$(+)=$ agree + strongly agree

The above table shows that $(56.9 \%)$ of the participants get anxious when they have been asked by the teacher in class without any preparation. Concerning error correction, it seems that the majority of Saudi learners in this study do not feel anxious towards receiving it in the 


\section{Macrothink}

classroom. Approximately (54.3\%) of the students accept error correction, while a limited of $(24.1 \%)$ do feel anxious towards receiving teacher feedback in the classroom.

\subsection{Causes Related to the Test}

Table 3 below shows the causes of speaking anxiety in relation to the test. This section covers two questionnaire items.

Table 3. Causes related to the test

\begin{tabular}{|c|c|c|c|c|c|c|c|c|c|c|c|c|}
\hline & \multicolumn{2}{|c|}{ SD } & \multicolumn{2}{|c|}{ D } & \multicolumn{2}{|c|}{$\mathbf{N}$} & \multicolumn{2}{|c|}{$\mathbf{A}$} & \multicolumn{2}{|c|}{ SA } & \multirow{2}{*}{$\frac{(-)}{\%}$} & \multirow{2}{*}{$\frac{(+}{\%}$} \\
\hline Items & $\mathrm{N}$ & $\%$ & $\mathrm{~N}$ & $\%$ & N & $\%$ & $\mathrm{~N}$ & $\%$ & $\mathrm{~N}$ & $\%$ & & \\
\hline $\begin{array}{l}\text { 17. I get upset due to } \\
\text { the method of testing } \\
\text { in the foreign } \\
\text { language class. }\end{array}$ & 16 & 13.8 & 12 & 10.3 & 17 & 14.7 & 25 & 21.6 & 46 & 39.7 & 24.1 & 61.3 \\
\hline $\begin{array}{l}\text { 18. I get nervous } \\
\text { when looking at my } \\
\text { grades. }\end{array}$ & 9 & 7.8 & 11 & 9.5 & 11 & 9.5 & 23 & 19.8 & 62 & 53.4 & 17.3 & 73.2 \\
\hline
\end{tabular}

Note: $S A=$ strongly agree, $A=$ Agree, $N=$ neutral, $\mathrm{D}=$ disagree, $S D=$

Strongly disagree, $(-)=$ Disagree + strongly disagree,$(+)=$ Agree + strongly agree

As seen in the table above, the majority of the students feel anxious, tense, confused and nervous when they are tested. The data showed that $(61 \%)$ of the participants feel anxious due to the method of testing while $(73.2 \%)$ of the students get worried and nervous when they receive their grades. It is clear that test anxiety is considered to be the major cause of FLA among Saudi students in this sample.

\section{Discussion}

This study aimed to examine the causes of foreign language classroom anxiety, with specific reference to speaking, among Saudi EFL learners.

\subsection{What Are the Main Causes of Saudi Students' Speaking Anxiety?}

Most of the research findings discussed below were in agreement with Horwitz, Horwitz and Cope (1986)'s three components of foreign language anxiety by which this study was guided. They argued that there are three related performance anxieties: the first one was called communication apprehension; the second was students' fear of negative evaluation; while the third was test-anxiety. Similarly, the current research found out that Saudi EFL learners 
suffered from communication apprehension from which they preferred remaining silent in class, they also had the fear from the negative evaluation either from their teachers or their peers and finally, it was also clear that the test anxiety constituted the highest anxiety level for Saudi learners.

To answer the research question of this study, both the semi-structured interviews and the online questionnaire were used. The qualitative study revealed that the major causes of female Saudi learners' speaking anxiety were referred to the teachers' role in raising or reducing anxiety, (including the lack of support, lack of understanding due to language barrier, the fear of teacher's negative feedback and time limitation for practicing the target language), lack of vocabulary, the weak educational system at schools, peer anxiety, and test anxiety. On the other hand, the results of the questionnaire indicated the causes of speaking anxiety which can be categorized into three main domains: causes related to the classroom atmosphere, causes associated with EFL teachers, and others related to the test.

The first and most important cause of Saudi learners' anxiety was the teachers' role in raising or reducing their level of anxiety. Participants were suffering from some unsupportive teachers whom they claimed to be an essential source of their foreign language speaking anxiety. The interview found that six participants claimed that their EFL teachers were neither friendly nor cooperative with them. This result is in agreement with Hamouda (2012) who found out that more than $(47.16 \%)$ of his participants expressed that they get more anxious when their teacher is very strict. At the same time, Hamouda added, many students $(71.06 \%)$ revealed that they feel relax when their English teacher responds in a friendly way. Moreover, some EFL teachers could have negative beliefs towards teaching. As an illustration, Alrabai (2015), found that most EFL teachers in his context believed that "it is necessary for the teacher to be intimidating at times, the instructor is supposed to correct every single mistake made by the students, group and partner work is not appropriate because it can get out of control, the teacher should do most of the talking in class, and the teacher is the ultimate controller and leader of the class" (P. 90).

Participants of this study reported that they experienced the fear of negative evaluation from their teacher which thus prevented them from answering any questions without preparation. This finding is supported by Öztürk \& Gürbüz (2014), who discussed some situations in which students feel stress while speaking inside the classroom and one of these situations was that they were sometimes exposed to questions immediately without preparation which leaded to their embarrassment while speaking in front of the class.

In the current study, there were some contradicting results. In the qualitative study for instance, the interviewees made it clear that they remained silent in class discussions due to their fear of making mistakes in front of either their teacher or their peers. In contrast, the quantitative results revealed that the participants did not have that fear of making mistakes in front of their teachers or classmates and considered making mistakes as a natural process necessary for their learning. This contradicting finding toward the fear of making mistakes in front of teachers and classmates was related to the students' feelings and since anxiety is a fluctuating emotion that differs from one person to another, so different perspectives could 
happen. In line with the qualitative results of this study, Mukminin et al. (2015) found in their study that participants perceived the teacher as more competent in English to the extent that they have the fear of making mistakes in front of him/her which consequently leads to their anxiety.

In addition to this, the qualitative study explored that Saudi students complained about the limited chances that they had to speak the target language inside their EFL classroom, where the teacher is talking more than the student. Students are having a chance to answer a little amount of questions during the class which is not improving their English language proficiency level. They needed to practice the language using different interesting activities arranged by the teacher, such activities will give the students the opportunity to speak the target language and practice it more. This finding is supported by Alsaraj (2014) who found that the English language was only taught as a subject. As a result, students have limited number of English classes and do not have sufficient time to communicate using the language.

One of the consistent findings in both the interviews and the questionnaire was the students' lack of vocabulary that causes their speaking anxiety. It is apparent from the questionnaire findings that more than half of the participants (55.2\%) agreed that they feel shy when they want to volunteer in class discussions because they don't have enough English words. This shyness drove them to be reluctant to speak or participate in their English language classes. In fact, Saudi students' lack of vocabulary may be because of their lack of reading. Raising their awareness of enhancing their reading skills is essential in order to enrich their vocabulary. According to Al-Masrai (2012), the Saudi Ministry of Education (MOE) reported that Saudi students "are expected to leave high school with a vocabulary size of around 3000 words" (p.15). He further added that there are only two studies which investigated Saudi learners' vocabulary knowledge: Al-Hazemi (1993) and Al-Bogami (1995). These two studies claimed that unfortunately Saudi students leave high school with low vocabulary knowledge as they got low grades in the vocabulary size tests. In other words, the weak Saudi learning system at schools resulted with a lack of students' sufficient vocabulary which therefore leads to their speaking anxiety.

With respect to the educational system in Saudi Arabia, the interview findings uncovered that seven out of ten participants suffer from the weak educational system at schools. This result could be referred to the drilling methods used at schools in Saudi Arabia, and to the limited time of teaching English. Forty five minutes per day is not enough to master a language. More time should be devoted to practice the English language in order for the EFL learner to improve. Teaching methods at the ELI were also considered one of the most important causes that induced speaking anxiety in EFL classrooms. One of the interviewees claimed that the teachers' overuse of the text book and the old teaching methods are not helping them to enhance their speaking ability. Student G (level 103) said: "We are using the books most of the time. The teacher is talking most of the time and we need to speak English as well in order to practice the language". Student B (level 102) reported: "From level one, the teachers do not teach us how to speak, they only focus on grammar and they do not make a class discussion in order to give us the chance to speak". This finding is consistent with that found in Yahya's study (2013), who asserted that utilizing traditional techniques in teaching the 
target language make students unwilling to communicate using it. As a result of utilizing drilling techniques and old teaching methods, students will become passive learners. This is supported by Alharbi (2015) who argued that the limited use of English inside the classroom affects students' speaking capacity. When students use the language a lot on a daily basis, it would definitely help them in improving their English language proficiency.

It was apparent from the questionnaire that giving a presentation in front of the class was considered one of the speaking anxiety provoking causes in the class. The questionnaire found that $56 \%$ of the respondents feel anxious while presenting any topic in front of the class. This is possibly related to their fear of peers' negative evaluation; their fear of mispronouncing words in front of the class and it also might be because Saudi students are not used to give a presentation at schools. This finding is supported by (Alsaraj, 2013) whose study explored Saudi students' struggles when presenting a live speech. Alsaraj's participants preferred recording their speech on an audio tape prior to the lecture and played it in class instead of presenting it live. According to Alsaraj, "the teaching methods typically used in Saudi Arabian school focus namely on listening, repeating, and memorizing information to perform well on exams; in-class presentations and speaking in class are not typical teaching practices in public education in Saudi Arabia". Thus, Saudi students were scarcely required to give in-class presentations. Therefore, the situation of giving a presentation in front of the whole class was highly embarrassing for them.

Peer's evaluation was one of the causes that triggered anxiety in EFL classrooms. Six participants, in the qualitative study, expressed their fear of the negative evaluation from their peers once they talk in English. Student B (level 102) said: "I am afraid if I make a mistake or mispronounce the words because my classmates may laugh at me". Moreover, student $\mathrm{H}$ (level 104) asserted: "I feel nervous if I speak in front of my classmates because if I say a wrong answer they may laugh". Then she added "I feel anxious when my classmates laugh at my pronunciation". It is clear from the participants' answers in the interviews that they feel anxious to talk in front of their classmates because of their fear of mispronouncing words, saying a wrong answer or to be laughed at. Alsaraj (2014) further claimed that EFL learners might feel they are taking a huge risk by speaking in class, because they might "answer a question incorrectly, mispronounce a word, or simply not speak fluently in the new language" (p.65). Therefore, the learners might avoid taking such risks by keeping silent in the class in order not to make mistakes and be laughed at by their classmates.

In addition to students' peer anxiety, the quantitative study in this research uncovered that $61.3 \%$ of the participants have high levels of test anxiety and $73.2 \%$ of them feel anxious about their grades in assessments. The participants of this study might feel upset with the method of testing in the foreign language class because of the lack of practice prior to the test. Students at the ELI receive a sample of the speaking test a week before the test which is not enough to practice the topics that is included in the test. This finding is consistent with the results of the study conducted by Khan and Al Mahrooqi (2015) that investigated the Foreign Language Communication Anxiety (FLCA) of Omani EFL learners at the tertiary level. They found that Omani students experience a high level of evaluation anxiety. This proves that evaluative situations in class are an obvious source of anxiety. Young (1991) 
noted that tests led to higher anxiety and a negative attitude towards instruction. According to Young (1991), task difficulty, the fear of getting bad grades and lack of preparation for a test are the most important factors that make learners worried. Another factor that increases test anxiety and decreases performance is time limit. For example, ELI students are given approximately three minutes in the speaking test in order to think and speak about a certain topic and this may increase their anxiety. This finding is supported by Ohata (2005), who found that learners sometimes felt pressured to think that they had to organize their ideas in a short period of time. In Ohata's study (2005), most of the participants indicated that they feared taking tests, because test-taking situations would make them fearful about the negative consequences of getting a bad grade. Regarding the ELI's speaking test, another teacher assessed the students beside their regular class teacher and this could possibly raise their anxiety level. This particular scenario may cause them to fear the other teachers' negative evaluation which could consequently affect their grades.

\section{Conclusion}

To sum up, this article investigated some of the major causes of foreign language speaking anxiety among Saudi female learners. It explored the perceptions of 126 Saudi students studying their foundation year at the English Language Institute (ELI), King Abdul Aziz University. To fill the gap in the literature, a mixed- method approach was utilized to produce a more reliable and valid data. The study findings uncovered that the main causes of the Saudi students' speaking anxiety were the teacher's role of raising or reducing anxiety, communication apprehension, lack of vocabulary, fear of peer evaluation, giving a presentation in front of the whole class, the weak background in English, and fear from the test. Future research is recommended to explore how the students cope with their speaking anxiety in their foreign language classroom by producing some solutions for teachers and curriculum designers. Investigating the causes of foreign language anxiety with other English skills, such as writing, reading and listening can also be valuable.

\section{Acknowledgement}

We are grateful to the ELI's population at King Abdul Aziz University in both the Women's Main Campus and the Women's Colleges for their support and participation in this research.

\section{References}

Al-Bogami, A. (1995). Teaching English vocabualry to EFL male students at intermediate and secondary public schools in Riyadh. (Unpublished master's thesis). King Saud University, Riyadh, Saudi Arabia.

Alharbi, H. (2015). Improving students' English speaking proficiency in Saudi public schools. International Journal of Instruction, 8(1), 105-116.

Alhamadi, N. (2014). English speaking learning barriers in Saudi Arabia: A case study of Tibah University. AWEJ, 5(2), 38-53. 
Al-Hazemi, H. (1993). Low level EFL vocabualry tests for Arabic speakers. (Unpublished doctoral dissertation.) University of Wales, Swansea, UK.

Al-Marsai, A., \& Milton, J. (2012). The vocabulary knowledge of university students in Saudi Arabia. TESOL Arabia Perspectives, 19(3), 13-19.

Alrabai, F. (2015). The influence of teacher's anxiety- reducing strategies on learners' foreign language anxiety, innovation in language learning and teaching. Innovation in Language Learning and Teaching, 9(2), 163-190

Alsaraj, T. M. (2014). Revisiting the foreign language classroom anxiety scale. L2 Journal, 1, 50-76.

Ansari, M. S. (2015). Speaking anxiety in ESL/EFL Classrooms: A holistic approach and practical study. International Journal of Educational Investigations, 2(4), 38-46.

Creswell, J. (2012). Educational research: Planning, conducting, and evaluating quantitative and qualitative research ( $4^{\text {th }} \mathrm{ed}$.). Boston, MA: Pearson Education, Inc.

Cutrone , P. (2009). Overcoming Japanese EFL learners' fear of speaking. Language Studies Working Papers, 1, 55-63.

Denscombe, M. (2014). The good research guide: For small- scale social research projects ( $5^{\text {th }}$ ed.). New York, NY: Open University Press.

Gardener, R. C., \& Macintyre, P. D. (1993). A student's contributions to second-language learning. Part II: Affective variables. Language Teaching, 26, 1-11.

Gordon E. M., \& Sarason S. B. (1955). The relationship between 'Test Anxiety' and 'Other Anxieties'. Journal of Per- sonality, 23, 317-323.

Hamouda, A. (2012). An Exploration of Causes of Saudi Students' Reluctance to Participate in the English Language Classroom. International Journal of English Language Education, $1(1), 17-34$.

Horwitz, E. K., Horwitz, M. B., \& Cope, J. (1986). Foreign language classroom anxiety scale. The Modern Language Journal, 70, 125-132.

Jamjoom, M. I. (2009). Female Islamic studies teachers in Saudi Arabia: A phenomenological study. Teaching and Teacher Education, 20, 1-12.

Kayaoğlu, M. N., \& Sağlamel, H. (2013). Students' perceptions of language anxiety in speaking classes. Tarih Kültür ve Sanat Araştırmaları Dergisi, 2(2), 142-160.

Khan, A., \& Mahrooqi, R. (2015). Foreign language communication anxiety (FLCA) among tertiary level omani EFL learners. Asian EFL Journal, 17(1), 57-89.

MacIntyre, P. D., \& Gardner, R. C. (1991). An instrumental motivation in language study: Who says it isn't effective? Studies in Second Language Acquisition, 13, 266-272. 


\section{Macrothink}

Mukminin, A., Masbirorotni, M., Noprival, N., Sutarno, S., Arif, N., \& Maimuna, M. (2015). EFL Speaking Anxiety among Senior High School Students and Policy Recommendations. Journal of Education and Learning, 9(3), 217-225.

Ohata K. (2005). Language anxiety from the teacher's perspective: Interviews with seven experienced ESL/EFL teachers. Journal of Language and Learning, 3(1), 133-155.

Öztürk, G., \& Gürbüz, N. (2014). Speaking anxiety among Turkish EFL learners: the case at a state university. Journal of Language \& Linguistics Studies, 10(1), 1-17.

Shams, A. N. (2006). The use of computerized pronunciation practice in the reduction of foreign language classroom anxiety (Doctoral dissertation, Florida State University College of Arts and Sciences, Tallahassee). Retrieved from http://etd.lib.fsu.edu/theses/available/ etd-11092006-171538/unrestricted/Shams_diss_Dec12.pdf

Shuying, Y. (1999). Classroom Speaking Activities [Electronic version]. English Teaching Forum, 37(4), 22.

Tseng, S. (2012). The factors cause language anxiety for ESL/EFL learners in learning speaking. An Interdisciplinary Journal, 63, 75-90.

Yahya, M. (2013). Measuring speaking anxiety among speech communication course students at the Arab American University of Jenin (AAUJ). European Social Sciences Research Journal, 1(3), 229-248.

Young, D. J. (1990). An investigation of students' perspectives on anxiety and speaking. Foreign Language Annals, 23(6), 539-553.

Young, D. J. (1991). Creating a low-anxiety classroom environment: What does language anxiety research suggests? The Modern Language Journal, 75(4), 426-437.

Young, D. J. (1992). Language anxiety from the foreign language specialist's perspective: Interviews with Krashen, Omaggio Hadley, Terrell, and Rardin. Foreign Language Annals, 2, 157-172.

Young, D. J. (2004). The teacher as a facilitator: reducing anxiety in the EFL university classroom. JALT Hokkaido Journal, 8, 3-18.

\section{Copyright Disclaimer}

Copyright for this article is retained by the author(s), with first publication rights granted to the journal.

This is an open-access article distributed under the terms and conditions of the Creative Commons Attribution license (http://creativecommons.org/licenses/by/3.0/). 